\title{
IfIISGUCDERGI.ORG
}

"IȘ, GÜC̣" ENDÜSTRi iLIȘKILERI VE INSAN KAYNAKLARI DERGISi

"IS, GUC" INDUSTRIAL RELATIONS AND HUMAN RESOURCES JOURNAL

\section{Choice and constraint in migrant worker acculturation: towards a new approach}

\author{
Barbara Wilczek \\ bwilczek@bournemouth.ac.uk \\ Eddy Donnelly \\ edonnell@bournemouth.ac.uk \\ Paul Freedman \\ pfreedman@bournemouth.ac.uk \\ Centre for Research in Management, The Business School \\ Bournemouth University
}

Ekim/October 2009, Cilt/Vol: 11, Say1/Num: 5, Page: 35-49 ISSN: 1303-2860, DOI: 10.4026/1303-2860.2009.0124.x

Makalenin on-line kopyasına erişmek için:

http://www.isgucdergi.org/?p=makale\&id=396\&cilt=11\&sayi=5\&yil=2009

To reach the on-line copy of article:

http://www.isguc.org/?p=article\&id=396\&vol=11\&num=5\&year=2009

Makale İçin İletişim/Correspondence to:

Yazarların e-posta adresleri verilmiştir. Writers e-mail was given for contact. 
(C) 2000- 2009

"İşGüç̧" Endüstri İlişkileri ve İnsan Kaynakları Dergisi

"İşGǚç" Industrial Relations and Human Resources Journal

Ekim/October 2009, Cilt/Vol: 11, Say1/Num: 5

ISSN: 1303-2860, DOI: 10.4026/1303-2860.2009.0124.x

Editör/Editor-in-Chief

Aşkın Keser (Kocaeli University)

Editör Yardımcıları/Co-Editors

K.Ahmet Sevimli (Uludağ University)

Gözde Yilmaz (Kocaeli University)

Uygulama/Design

Yusuf Budak (Kocaeli Universtiy)

\author{
Yayin Kurulu / Publishing Committee \\ Dr.Zerrin Firat (Uludăg University) \\ Doç.Dr.Aşkın Keser (Kocaeli University) \\ Prof.Dr.Ahmet Selamoğlu (Kocaeli University) \\ Yrd.Doç.Dr.Ahmet Sevimli (Uludağ University) \\ Yrd.Doç.Dr.Abdulkadir Şenkal (Kocaeli University) \\ Yrd.Doç.Dr.Gözde Yilmaz (Kocaeli University) \\ Dr.Memet Zencirkıran (Uludağ University)
}

Uluslararası Danışma Kurulu / International Advisory Board

Prof.Dr.Ronald Burke (York University-Kanada)

Assoc.Prof.Dr.Glenn Dawes (James Cook University-Avustralya)

Prof.Dr.Jan Dul (Erasmus University-Hollanda)

Prof.Dr.Alev Efendioğlu (University of San Francisco-ABD)

Prof.Dr.Adrian Furnham (University College London-İngiltere)

Prof.Dr.Alan Geare (University of Otago- Yeni Zellanda)

Prof.Dr. Ricky Griffin (TAMU-Texas AEM University-ABD)

Assoc. Prof. Dr. Diana Lipinskiene (Kaunos University-Litvanya)

Prof.Dr.George Manning (Northern Kentucky University-ABD)

Prof. Dr. William (L.) Murray (University of San Francisco-ABD)

Prof.Dr.Mustafa Özbilgin (University of East Anglia-UK)

Assoc. Prof. Owen Stanley (James Cook University-Avustralya)

Prof.Dr.Işık Urla Zeytinoğlu (McMaster University-Kanada)

Danışma Kurulu / National Advisory Board

Prof.Dr.Yusuf Alper (Uludağ University)

Prof.Dr.Veysel Bozkurt (Uludağ University)

Prof.Dr.Toker Dereli (Işık University)

Prof.Dr.Nihat Erdoğmuş (Kocaeli University)

Prof.Dr.Ahmet Makal (Ankara University)

Prof.Dr.Ahmet Selamoğlu (Kocaeli University)

Prof.Dr.Nadir Suğur (Anadolu University)

Prof.Dr.Nursel Telman (Maltepe University)

Prof.Dr.Cavide Uyargil (İstanbul University)

Prof.Dr.Engin Yildırım (Sakarya University)

Doç.Dr.Arzu Wasti (Sabancı University)

Dergide yayınlanan yazılardaki görüşler ve bu konudaki sorumluluk yazarlarma aittir.

Yayınlanan eserlerde yer alan tüm içerik kaynak gösterilmeden kullanılamaz.

All the opinions written in articles are under responsibilities of the outhors.

None of the contents published can't be used without being cited. 


\title{
Choice and constraint in migrant worker acculturation: towards a new approach
}

\author{
Barbara Wilczek \\ bwilczek@bournemouth.ac.uk \\ Eddy Donnelly \\ edonnell@bournemouth.ac.uk
}

\begin{abstract}
:
Following the unprecedented level of immigration into the UK in recent years, the issue features on a number of policy agendas, notably those around employment, where the impact of migrant workers and their relationships with indigenous workers have become topics of considerable debate. In the light of the existing evidence around migrant workers' experience of being de-skilled and de-valued (e.g. Anderson et al 2006, Currie 2007) as well as indigenous workers' potential hostility emerging from their fears of wage depression and substitution, the important question of how migrants negotiate their relationships within workplaces remains largely unexplored. Assuming that migrant workers are likely to be an important part of the national economy for the foreseeable future, it is time to ask the questions of how migrants negotiate their 'fit' into the British work environment, and how that is shaped and managed over time. In the first part of the paper we critically review the traditional conceptions of immigrant acculturation into the host society. The key concern of contemporary theories of acculturation has been with identifying individual's orientations and how these relate to psychological adaptation (e.g. Berry 1990, Berry and Sam 1997). Significant here are also the models that recognise the interplay between hosts and migrants in forming the dispositions of the other. For example, the work of Bourhis and Montreuil (2001) suggests a variety of forms that may arise from combinations of migrants and hosts in relation to the preferred strategy of each. More recent adaptations of these frameworks have attempted to address the context dependency of acculturation strategies adopted by both migrants and indigenous members (e.g. Navas et al 2005). These latter models reveal important aspects of the divisions between public and private domains, real and ideal situations, and the ways that these can change over time. However, it is our contention that they remain limited by their location in an overly cognitive framework and a positivist research paradigm. In the second part of the paper we critically engage with this research and apply a discourse analytic approach to acculturation as a means of addressing some of the issues. We argue that despite their sophistication extant models reproduce overly static and de-contextualised accounts of acculturation. For instance, participants are methodologically fixed into a restricted number of mutually exclusive positions (either to integrate or segregate). Moreover, these positions are seen to point towards the same underlying attitudes within and across particular studies despite their taking place in different socio-historical settings (Bowskill et al 2007), most particularly labour markets. Further, such models assert the individualistic nature of the processes involved, glossing the socio-political construction of the meaning and value of acculturation. Locating the desire for, or opposition to, integration in the minds of individuals risks reifying the construct and shutting down the ways in which social practices serve to privilege or denigrate particular strategies, as well as placing the burden of adjustment on those least able to bear it. In place of these static typologies Bowskill et al suggest acculturation issues are better analysed through approaches that pay attention to 'the micro-level construction and functions of... broader interpretive resources' (796) but which are supplemented by a 'macro-level attention to more global patterns of acculturation discourse and their implications for power relations' (796). Following this approach we propose and operationalise a research agenda that pays close attention to the everyday accounts proffered by workplace actors detailing their 'action-oriented function' (Bowskill et al 2007: 799) and exploring their patterning by broader forces within the workplace and beyond. We present evidence around the ways in which forms of integration are positioned as moral 'goods'; the role that indigenous workers, employers and trade unions play in such positioning; and the ways in which such positioning is accepted/contested in everyday rhetorical practice. As such the research shows how influential are the types of relationships between differing migrant groups, but also among members of the in-group, in constructing identity. For instance, based on their own observations and experiences of working next to each other, Polish individuals undergo a continual process of becoming in which they set up a contrast between themselves and other members of the in-group but also with the Romanian workers who are constructed implicitly as Poles' opposites. This positions Polish migrant workers outside certain anticipated norms of behaviour but also under an expectation to learn them.
\end{abstract}

Keywords: Migrant worker, Acculturation, Worker Acculturation 


\section{Introduction}

This paper presents a further development of the ideas presented by the authors in 2008 (Donnelly et al.). In it we outline an alternative approach to understanding the processes of acculturation experienced by migrant workers and put this approach to work through a preliminary analysis of the story of a Polish worker.

In the context of unprecedented levels of inward migration to the UK, notably from CEE countries, over recent years, the issue has become the focus of much attention, from a number of quarters. However, perspectives on CEE migrants residing in the UK are ambiguous. They are portrayed in some quarters as 'good workers' who are praised for possessing a strong work ethic, positive attitudes to work, high levels of commitment and a willingness to work hard for low wages: factors that explain why they now constitute a significant proportion of labour throughout the UK (People Management, 2006), Even the House of Lords' somewhat negative report on the economic impact of immigration (House of Lords, 2008) acknowledged the diligence and motivation of most migrant workers. Likewise, when commenting upon the 2006 figures from the Worker Registration Scheme, the Home Office Minister Tony McNulty (Press Office, 2006), said that A8 migrants "are benefiting the UK, by filling skills and labour gaps that cannot be met from the UK-born population". Accordingly, many migrant workers have been, at least until relatively recently, officially perceived to be a valuable addition to the resolution of labour supply problems within sectors of the British economy.

However, indigenous workers may feel less sanguine towards this influx of migrant labour into the domestic job market. Despite the presumed attributes of migrant workers and their appeal to recruiters, we might anticipate a certain amount of hostility amongst indigenous workers, arising primarily from their fear of wage suppression and job replacement. On the other hand, migrants might not necessarily view themselves as being in a better economic position than indigenous counterparts. A growing body of research has provided evidence for migrants being de-skilled, de-valued, exploited and discriminated against, in terms of their pay, conditions and employability (Anderson et al., 2006; Currie, 2007; Fitzgerald, 2006, 2007; French and Mohrke, 2006; Gaine, 2006). Given this context, issues around workplace acculturation become important considerations. For migrants attempting to settle, even for a temporary period, the issue of how to manage relationships with those around them becomes an urgent and important one. Even though work applications from the eight accession countries have fallen to their lowest level since they joined the EU in 2004 (Home Office, 2009), we argue that particularly in the light of current economic recession the issue of migrant workers' acculturation in the workplace remains an important one.

The research agenda to date has largely been dominated by exercises in mapping, through which migrants' origins and profiles have been charted alongside their geographical dispersion and concentration. In addition their utilization by occupational type has been a focus of research effort (e.g. Anderson et al., 2006; Currie, 2007; Evans, 2007; Home Office, 2007; Lsc, 2007; Salt, 2006; Spencer et al., 2007). Welcome though these findings are, few of the available sources of knowledge specify how the social and reciprocal exchange relations between migrant and indigenous workers, employers and/or trade unions might be characterised at an individual company level, how these might evolve over time and what might influence migrants' choice over their acculturation into the workforce. The focus of this study is on investigating what shapes people's choices and how a particular group of migrant workers position themselves within the complex interplay of work environment enablers and constraints. Such an insight attempts to complement the existing literature by providing a richer understanding of the 
reality of migrants' work experiences and their everyday struggles.

It is important to acknowledge that migrants' views and strategies of acculturation may be highly dependent on their plans with regard to settlement intentions (McGovern, 2007). The nature of much recent migration from CEE countries differs from the previous migratory inflows into the UK in terms of mobility. On the one hand, a new legal status and ability to claim EU citizenship rights could encourage more prolonged stays and greater permanence. However, mobility could increase as borders are easier to cross, thus facilitating more back-andforth movement. Consequently EU enlargement represents a potentially crucial transition in relation to the strategies of recent migrants. Their options often become open and dependent on potential opportunities as when and where these appear. These temporary or even circular movements, however, not only make recent migration distinctive but also pose another set of issues. Migrants' potential lack of attachment to the new country, neighbourhood, workplace as well as indigenous workers, employers' lack of involvement in building sustained relationships might result in developing diverse types of work relations.

Bearing the above in mind but also assuming that migrant workers are likely to be an important part of the national economy for the foreseeable future, it is time to ask questions of how recent migrants negotiate their 'fit' into the British work environment, and how this is shaped and managed over time. Given the perceived migrant workers' exploitation and indigenous workers' fears over substitutability, a number of choices over adaptation strategies become available on both sides of the relationship. The dilemma whether to 'rub along' or fully assimilate is managed everyday, in particular in the work environment where the potential of tensions dominating relationships between sets of workers is potentially severe due to the common presence of mutual misgivings.
These issues are addressed by complementing traditional typologies of acculturation with an approach that pays close attention to the process itself. Due to the dynamic nature of migrant workers' everyday negotiation of their acculturative choices, importance has been given to ways in which workplace relationships between migrant and indigenous workers as well as employers and trade unions are shaped and maintained over time. It is argued here that investigating ways in which migrants come to choose their strategies will provide better insight into their working life than identifying the strategies alone. Because the aim of the research agenda is to pay close attention to everyday work experiences, the research methods used are those of participant observation and autobiographical narrative interviews. Such an approach gives not only an insight into migrants' acculturation practices but also illuminates the milieu in which daily encounters between workplace actors take place.

\section{Traditional concepts of acculturation}

Modern theories of acculturation processes are a major resource in the understanding of the issues around human behaviour and experiences in the context of migration and mobility. Models are characterised by orientations towards acculturation choice being mapped onto forms of typological matrices, in which migrant choice is claimed to be determined by preferences towards 'cultural maintenance' and 'contact participation' (e.g. Bourhis et al, 1997), or by relationships between host and migrant communities (Piontkowski et al, 2002). From such matrices strategic choices 'available' to migrants are simply 'read off', with choices ranging from integration through assimilation, separation and marginalisation. Such matrices commonly have the overt intention of identifying 'consensual', 'problematic' and 'conflictual' relations between host and migrant communities, and are rooted in cognitive models that are pursued through largely positivistic forms of research. Such research 
is commonly conducted through responserestricted questions that attempt to tap into the respondent's acceptance or rejection of either host or own culture.

A sophisticated version of this approach is found in the work of Navas and colleagues (2005, 2006, 2007). In making a distinction between preferred and adopted strategies they introduce an element of contingency into the analysis, such that migrants are seen to adopt strategies differentially according to constraints such as poor language skills, and the situation that confronts them. This leads to the possibility that acculturation strategies vary across domains. In particular Navas et al (2005) assert the possibility that the workplace may be a domain of relatively likely integration because it represents less of a challenge to migrant's core values.

\section{Moving on}

These latter models reveal important aspects of the divisions between public and private domains, real and ideal situations, and the ways that these can change over time. However, despite their sophistication, extant models can be seen to reproduce overly static and de-contextualised accounts of acculturation. Participants are methodologically fixed into a restricted number of mutually exclusive positions (e.g. they can either integrate or assimilate). Such work typically relies on Likert-scale questions about cultural attitudes, practices, or identities, as well as questions about distress, life satisfaction and other measures of adaptation. It seems clear that these positions are supposed to point towards the same underlying attitudes within and across particular studies, despite their taking place in different socio-historical settings (Bowskill et al., 2007), most particularly labour markets.

Further, such models are seen to assert the individualistic nature of the processes involved, glossing the socio-political construction of the meaning and value of acculturation. Assumptions that people of certain characteristics are likely to adopt certain options (e.g. perceived similarity between two gro- ups increases the possibility of integration or assimilation strategies) ignores the potential influence of other factors, the context in which acculturation takes place and the dynamic nature of interpersonal relations. Locating the desire for, or opposition to, integration in the minds of individuals risks reifying the construct and shutting down the ways in which social practices serve to privilege or denigrate particular strategies, as well as placing the burden of adjustment on those least able to bear it.

Moreover, despite the welcome incorporation of context in Navas et al's (2005) model, the suggestion that different strategies might be adopted in a limited range of life domains (e.g. family, work, social relations) leaves the conception of context somewhat static. Even addressing the importance of intergroup relations draws attention to comparisons between the classifications assumed to be held by majority and minority groups. In this way differences and distinctions are reified and the negotiation and contestation over acculturation remains unseen. Consequently, what becomes important is what strategies different groups adopt, thereby neglecting the significance of the process itself, in particular how individuals come to identify themselves and what factors shape their way towards or away from certain strategies on a day to day basis. For us, the significant issue is how migrants arrive at and live their acculturation choices and constraints. This is a concern increasingly shared by others. For example the contributors to the special edition of the International Journal of Intercultural Relations (2009) all, in various ways, point towards forms of thinking and researching that attempt to transcend the perceived limitations of conceptions of acculturation offered by traditional models. To illustrate this point Chircov (2009a, $2009 b, 2009$ c) commends a return to the methods and conceptual frames of Thomas and Znaniecki (1918). Through such work Chircov argues for studies that identify and illuminate the experiences and meanings of acculturative activity, in particular in interactions between migrants and 'representa- 
tives of the host society' (2009b:102).

A contemporary approach in this vein is offered by Bowskill et al's (2007) discourse analytic approach.

\section{A Discursive Turn}

For Bowskill et al the shortcomings of extant models are best overcome through a perspective that shifts to:

examining the global patterns of acculturation discourses as they are rhetorically configured to accomplish a variety of action-orientated, micro-level social actions. The focus is on the ways that particular accounts of acculturation are constructed to achieve particular argumentative effects (2007: 796)

By this means the action-oriented negotiation and deployment of acculturation discourses is revealed. Further, Bowskill et al supplement the micro-level construction of these interpretive resources with a concern for a macro-level analysis which draws attention to power relations:

....attention to local level discursive practices occurs in tandem with concerns over the pervasiveness of particular repertoires and what might be gleaned from this regarding existing power structures and the 'taken for granted' (2007: 796)

This approach presents a distinct challenge to the traditional typological approach outlined earlier. Through a focus on ordinary language and its effects it promises to deliver a fluid rather than a static conception of acculturation, allowing a close examination of the ways in which particular positions are accepted/contested. In this way positions are revealed as negotiated and reproduced rather than simply treated as preordained. The power of Bowskill et al's approach is well illustrated through their study of British print media debates surrounding the issue of faith schooling in the UK. Their analysis of press commentary illustrates the ways in which the banality of language served to privilege integration as the optimal response to diversity, while simultaneously denigrating other positions. Further, integration was often used synonymously with assimilative outcomes while assimilation itself was never directly alluded to. In their example, Muslims who were expected to integrate were positioned as current 'outsiders' to the assumed 'in-group'. This 'expectation' however served implicitly to position Muslims as subjects of simultaneously privileged mainstream requirements. In this fashion Muslims were pressured, insidiously, to conform to the 'moral good' of assimilation.

Drawing on the above, it might be assumed that migrant workers similarly find themselves being positioned and pushed by forces within the workplace in one direction, presumably towards integration. What remains to be explored is how this process takes place.

\section{A Way Forward}

In line with what has been suggested so far, a migrant's identity can be understood as an ongoing process of construction and reconstruction, a category of everyday experience used by individuals to make sense of themselves in a particular situation and in relation to particular people, who might be defined as 'similar' or 'different', 'us' or 'them'. Since identity is regarded as a process rather than an end product, the key question is not what it is but how it has been formed, retained and changed over time in the course of various experiences and what are the factors crucial to its shaping. In the context of the workplace this leads to a focus on significant actors and dynamic nature of employment relations within the workplace.

Daily interplay at work becomes the point of departure for exploring the ways in which differing groups of workers enact and contest acculturative outcomes such as whether to 'rub along' together or to adopt more distancing tactics. Such an approach offers opportunities for recognising the ways in which dominant and 'transgressive' positions are mediated and reproduced rather than being seen as givens to be 'read off' 
from actors. Also, the importance of the research context is highlighted, recognising that much sustained, regular, on-going relationship/interaction between migrants, indigenous workers, and others, takes place in a workplace where people bring in their perceptions, expectations and habits that can be reinforced, changed or mediated by others. What follows is an account of fieldwork designed to put this framework into action.

\section{Method}

Data has been generated by an extended period of participant observation and narrative interviews with Polish migrant workers in a local food processing plant $(X)$ on the South coast of England. This plant was chosen as a site where large numbers of migrant workers, predominantly of CEE origin, are employed. In the contemporary discourse around 'new wave' migration Polish workers are commonly identified as the largest and most visible element of that influx. They are thus regarded as a suitable proxy for the migrant work experience. It is important to note that British workers form only a very small part of the shop floor workforce in X. In addition to Poles there are large numbers of Romanians, who were the first CEE workers to be recruited, as well as small numbers of Portuguese, and Bangladeshis.

\section{Participant Observation}

A focus on everyday encounters between actors in the workplace suggests forms of ethnography as a candidate for the research approach.

Access to the research site was negotiated and relatively unrestricted right of entry to the factory was granted. The first stage of data collection commenced on the factory shop floor and was conducted by the principal author over a period of three months. Observations took place across a number of departments throughout the shop floor and with different shift teams. During this time the researcher actively participated in food production and packing. This enabled her to work alongside co-workers from a number of different countries, as well as indigenous workers and managers.

Many migrant workers displayed an openness and enthusiasm for working and talking to the researcher who was perceived to be not only 'new blood' but also a link between them and the 'managers upstairs'. However, due to the physical attributes of the research setting (noise of the working machines) combined with the nature of factory work itself (working on the line) people's potential willingness to talk about themselves and the factory could rarely be utilised apart from short break times in the canteen. Consequently observation has been followed up by a series of interviews designed to pursue themes of interest. The field notes of the factory setting, rules of behaviour, and types of relationships people have with each other, as well as their attitudes and perceptions on certain issues have provided a rich source for contextualizing the interviewees talk.

\section{Narrative Interviews}

Interviews were conducted using narrative forms with a number of respondents. This form of interviewing was chosen due to its inherently social character, revealing personal experiences and broader patterns of institutional change:

The stories people tell, from such a perspective, are not isolated, individual affairs, but reflect and constitute the dialectics of power relations and competing truths within the wider society (Bron and West, 2000: 159)

This technique takes language seriously and acknowledges it to be a medium of exchange. In this way the dynamics of migrant workers and their acculturative choices were revealed.

\section{Preliminary Analysis}

Early analysis confirms the expectations of our approach in revealing acculturative strategies of migrant workers that evolve as a result of new circumstances in which they find themselves. Individuals make a number of decisions, whether strategic or more reac- 
tive, in terms of their fitting into a new environment but these are always likely to reflect their current situation. Thus, even though an individual makes a particular decision, it may change as time elapses and new conditions prevail. How these shape migrants' acculturative choices will be illustrated by the story of an interviewee: Kasia.

Kasia

Kasia is a 25 years old university educated migrant from Poland. She came to the UK in 2006 together with her class mate who had already had an employment contract arranged with one of the agencies in Southampton. This was a largely spontaneous decision, on the back of a breakdown in a personal relationship. He promised Kasia to fix her up with a job once they got to England, but the reality turned out to be different.

He hadn't mentioned before that I would have to fight for a contract myself. I just came here completely unaware.

However, she quite easily found a job through a Polish recruiter who gave her a lot of papers to fill in and told her that an English language test would be conducted when she got to the factory. Then she was given the address. Kasia got to the place (a food processing plant), went through some medical examinations and passed the language test. After two days of safety and food hygiene training, however, she still did not know what kind of job she was supposed to do. On the third day she started having doubts.

So we put on those boots, coats and caps (...) when I saw myself in the mirror I couldn't believe it was me (...). We went downstairs and those people were like some ants... and we like aliens, as if nobody noticed us. But later we could feel that they were saying of us: 'O they are the ones who started with contracts straight away.' There was already that accusation of starting a job with the company instead of going through the agency first, like everybody else... When I saw the place I broke down, I completely broke down. For the first 3 hours I couldn't shake it off...During my first week I met a boy who lived in my village and I met him in X. And this is how my story began.

...When I was calling my parents I was telling them that I worked in some Chinese factory. When you enter the factory you have to use that passageway with wires and you feel as if you were going to be executed in a moment or like in a prison where prisoners go for walks.

For Kasia, her early experiences of the plant seem overwhelming. Already she notes hostility among differing groups of workers, not least compatriots, and the sheer physicality of the setting seems to affect her physically too. This accords with fieldnotes gathered during the phase of participant observation 'the atmosphere of the factory reminds me of a modern labour camp type....or maybe I slightly exaggerate....but the pace of work is actually unbelievable and it is enough to slow down a little bit to hear your supervisor's voice behind your back to hurry up'. This imagery of the labour camp is worthy of note, particularly in the context of Poland's history where such a metaphor has striking potency. It was an image also used by others and resonates throughout the study. It is often referred to in relation to the physical attributes of the plant but also in relation to work organization, such as work pace, status rivalry, and close supervision. One may suppose that this strong reaction to the workplace is sharpened by the contrast between the aspirations of highly educated young workers and the brute reality of Fordist food production.

For Kasia the beginning was a tough time. Line leaders did not let her do her designated job, there was no training, and nobody showed her her duties. So she was only cleaning around the lines, helping others and watching how things are done. The first day was a shock but she did not want to go home to Poland, she did not want to give up so quickly. Still, she cried every time she got home and kept calling her parents.

It was autumn when she started working in 
the factory and Christmas came quickly but she could not go home - the factory is always busy at Christmas time and employees are not allowed to take holiday until mid January. So she spent Christmas with a Polish friend, mainly crying on the phone when calling her family and friends back in Poland.

This migration cost me a lot at the beginning. Separation from my family, it was really hard time for me at the beginning. Christmas time was particularly tragic. When you can't take any days off and you can't go home for Christmas. It's been like that for three years, or Easter even for four years. This is the worst when you have to stay here for Christmas. But at the beginning, when I was alone at Christmas time, I thought I would go completely crazy.

Kasia feels extremely bad as a result of new circumstances she finds herself in and keeps coming back to the place she is comfortable with. She does it within limits of available possibilities - she cannot go home so she escapes by calling her family and friends who stayed in Poland. Her contact with Poland is now limited but that makes it more valuable.

Now, after 3 years, she is used to spending Christmas away from family. She met her husband in the factory and she is starting a new family with him so going home for Christmas is not that important anymore

I think that I have acclimatized myself here. At the beginning of course I was scared of everything. I was afraid of going out...now I'm ashamed of talking about it but I was looking around on the street, I don't know, to make sure that nobody followed me. I had it somewhere inside of me that you have to be very careful, it was until I became accustomed to it. So it was very difficult at the beginning....but now it's ok. The only thing I would like to change is the job into something more developmental.

\section{Later she comments:}

By saying that I have acclimatized myself
I mean that I have started feeling at home here, as if it was my place in the world. It started to feel ok, I started to feel good here. I love this town and I don't want to leave. It is beautiful. At some stage I just started to feel that this is my place, place where I want to be. It's not like I'm a Pole and I want to go back to Poland. No, I don't want to go back to Poland. I had been thinking whether to come back, save some money and come back, or stay for a really long time but I finally decided to stay because I feel good here. We decided to buy a flat here, to start our family here because England is not a bad country, right? It is a country of many opportunities and the only thing you have to do is reach for it. And I want to do that, I feel that I can achieve something here, more than in Poland because I have always wanted to speak English, to speak English fluently and I want to do something more to speak fluently. Because if I want to stay here permanently then I don't want other people to do things for me. I just want to be able to develop and live normally. I don't miss Poland, or my family that much, because even if you live in another city in Poland you can still miss your family, it is normal. I just do miss other places, because this place I have found is my place. I don't know what's going to happen in 2 or 3 years time. Now I know it's ok.

Here Kasia exhibits many of the concerns that a new migrant would express in moving to an urbanised setting in a new country, from a familiar rural context. She now seems to acknowledge a relatively settled existence, except in relation to the workplace, suggesting that she has been able to reach an accommodation with aspects of her life outside the workplace, but not within it. She elaborates this in more detail:

Generally speaking, $X$ as a place where... right now I have that comparison, when I work with those managers from upstairs, those who manage the factory and those managers from downstairs...there is that difference in being well-mannered among those people, hmm in one's man- 
ner, generally speaking that self-preservation instinct of people who work in the office and those who work in production, on the shop floor...there is an enormous gap. Of course, not in all case because there are also well-mannered people on the shop floor, I can't pigeonhole people, but in majority...I'm not talking about those ordinary workers who work on the line, [and] pack; I'm talking about those who manage, about line leaders, team leaders, managers. This is how I see these things; that there is no respect for workers. Nobody talks openly about discrimination; and there is discrimination! There is no way they could excuse themselves that there is no discrimination. For example, one day...if we are talking about Romanians, majority of them are of the Orthodox faith, right? Their Easter was week after ours and when we had Easter people couldn't take any day off and in addition to that there were no agency workers because presumably they had been told they weren't needed. When Romanians had their Easter a week later, agency workers were not sent home while 5 Romanian workers from our team were allowed to go home. They always find some excuses, either lack of experience, or inability to evaluate situations properly, and how are we supposed to feel? Even if we don't have that day off you can always make some other arrangements. In another department, for instance, they could come earlier to work and leave at $2 \mathrm{pm}$.

For Kasia the realities of the workplace are structured by discrimination, among both shop floor workers and among the hierarchy of management. This is her first mention of Romanians, but they form an important part of our story, being the focus of a number of respondents. They form a large proportion of the line leaders and are commonly employed on differing terms to the Poles and other workers, typically being signed up to full contracts from the start of employment. Poles and others typically are obliged to go through agencies and only gain full contracts later. From Kasia's story we can deduce a tension between the Romanians and others, and an apparent willingness on the part of Romanian managers to favour the Romanian workers. She draws a contrast between the English managers at higher levels in the organization and those on the shop floor, noting that the majority of those upstairs behave in an acceptable fashion.

Kasia recounted a number of stories in which the nationality of the participants was held to be a factor in their behaviour:

.....my manager was mostly angry about the fact that I didn't accept everything he was telling me, that I was mouthing off. But it is impossible for me that somebody insults me and I keep quiet. He has no right. He can and I can't? Why? Because he is the manager and Romanian and I am Polish and his subordinate, right? This is how I see these things. But, hmm, I don't know why it is like that. Because the previous manager, he was English, and he really treated everybody equally. There were no exceptions. If someone did something wrong then the appropriate measures were taken against that person, no matter whether he/she was Polish, Romanian, English, Czech or Slovak, anybody...

I think that it is as if there was a fight between Poland and Romania at X. Because there are a lot of Poles and a lot of Romanians. And, Poles also want to achieve something there, right? But Romanians are the ones who want to rule there, but Poles don't want to give up. Poles are very tenacious nation so there are many arguments, conflicts. But when majority of managers are Romanian... why don't we have a single Polish manager? Because Romanians always block Poles; because Romanian manager will never let a Pole make a mark, he will never let a Pole succeed or come to "power" that he has. Because then they would be equal, and it can never be! A Romanian is supposed be above a Pole.

These fragments of story illustrate the ways in which questions of nationality and identity are imbricated in common tales of workplace strife 
and friction. For Kasia there seems to be a tension between being Polish and having to be subservient to a Romanian manager. In response to a question about who the managers should be, she posits a notion of 'neutrality':

Interviewer: You also mentioned during our last interview that the only Englishman who works in your department is so obedient to the Romanian manager and that he is shaking in his shoes and that you are surprised with that behaviour. Why do you find it so peculiar?

Kasia: Because he is English, he is at home, this is his country and I think that in such a factory, in such a place, an English person should be a manager, I'm not talking about those upstairs, but those downstairs who manage other people should be neutral, somebody who would treat everybody equally, who is objective. So far there was only one objective manager, he was English, others were very biased. But going back to that English boy who has been working in that department for 12 years, ehmm, I can't imagine that such a person ehmm his English is perfect, after all he was born here, and it is so easy to find a job here, it isn't difficult. If you have some skills and willingness to do something, you will get that job. So, I'm surprised, that an Englishman, young Englishman who would wear a suit and tie at work and do something really cool, he packs pies and is obedient to a manager who is Romanian and he is afraid of him; it shouldn't be like that! He is English! I don't know, maybe it is his lack of ambition, maybe he simply doesn't want it, right? But if I were him, I would never let it happen. I would tell them that I want to try, I would want them to offer me something better because it is my country so why should I be disadvantaged because of others? It is right that we come here and take jobs from Englishmen but on the other hand, as we can see from that example, I don't think they want that better job. Are they lazy, or unambitious?
For Kasia such 'neutrality' is bound up with 'objectivity' such that people will be treated the same, and she sees English managers as the appropriate persons to carry this out. In addition she condemns the idea that an English person should be subservient to Romanians. There is an element of fantasy about Kasia's image of British managers, and indeed of British workers. What is missing is any sign of overt, or even implicit pressure to conform to British ways of being.

Things in the workplace have also changed for her. She was offered to participate in a new project in the factory, but some problems endure:

I think I have worked out for me quite a good position in the factory because previously...I was Quality Assurance but now I mean, I'm still that QA but I'm not doing that job, I'm working on documents, there is that new project in X, I'm trying to work on those documents but my [Romanian] manager keeps disturbing my work. And the situation right now is that I really want to do that job because it is very interesting and it somehow develops my skills and he is trying to obstruct it because, I suspect that, it is because I'm not from his country, other nationals are trying to achieve something here.

Promotion at work has reinforced Kasia's positive attitude towards the place. She does not refer to the workplace as 'a Chinese factory' now, but just' the factory', as if it was already a different place for her. She might feel she starts belonging to this place because this is where her abilities, skills and characteristics have been recognised.

But this has not been done without fighting for rights and striving to change at least some of the factory behaviours. Her problems with supervisors and managers from the shop floor started straight from the beginning because they did not show employees any respect:

Let's treat each other like humans...but he [the manager] made me cry just on the shop floor (...) and I'm this kind of person who will never let other people of- 
fend or humiliate me...in some way he was doing emotional damage to me, he was making fun of me in front of other employees.

For her this is where all conflicts start because people do not respect each other. While some people accept the humiliation as long as they are paid for the job they are doing, she values honour more than money.

They don't have easy life with me; I'm not quiet and if I don't like something I just talk about it. I'm not going to sit as quiet as a mouse because I earn for living here. We are in the European Union, and I can work in its every country, and I shouldn't be discriminated against or treated differently.

Kasia has become an active trade union member and, together with her shop steward, she writes a lot of petitions and complaints about unfair and discriminatory acts that take place on the shop floor.

Kasia seems to be very sensitive to observing the most basic human rights and she disagrees with ways employees are treated in the factory. Despite the previous impression of her readiness to integrate, she does not accept everything that takes place in the plant. She gets upset and helps her compatriots when they face unfairness.

Because of Kasia's increased contact with the managers from upstairs, her English has become more fluent and she has become proud of herself that she can organise everything on her own and she can say everything she wants to say. And she realises that it is very inconvenient for the managers from the shop floor.

They don't really like me, they would rather get rid of me (...) They think that what I'm doing now [new project] is unnecessary (...) they don't understand how important it is (...) They don't care about the project so they are trying to obstruct my work by not giving me time to do the paperwork.

Kasia feels that Poles are discriminated against by Romanian managers and therefore she does not see her future on the shop floor. Her ambition is to develop professionally and work in a place she feels good at, for instance in an office, and she feels she is on the right track for this. Working upstairs would enable her to learn idiomatic English. That would help her to live 'normally' in this country - to understand everything people say to her and avoid the embarrassment of misunderstanding, or to watch TV without checking words in a dictionary. These things are important if she plans to stay in the UK permanently. She has just got married and bought a flat. She would like to have a baby and if it is a girl she will name her Zuzia - her roots are Polish so the name has to be Polish as well. Kasia is proud of her Polishness, culture she was brought up and religion. She says:

I will never be one of them. I'm a Pole and I'm proud of my nation. I'm proud that we are so intelligent that we can come to a foreign country and speak fluently in their language, live normally here without any problems. This is what I'm proud of, more than I would be if I was an Englishman, for example. I'm not going to apply for a British passport, that's for sure. I'm proud that I'm a Pole.

\section{Discussion}

This story illustrates a number of important issues about the ways in which recent migrants negotiate their acculturation choices in the contemporary UK workplace. Among the familiar account of homesickness and the shock of mass food production, Kasia's account is suffused with notions of Polishness that she sees to be threatened. From the beginning she identifies differential treatment between Poles and others in respect of religious observance, as well as privileges offered to nonPoles such as overtime opportunities and line management opportunities. She tells a story of acclimatization however, in which she posits herself as becoming accustomed. Her primary focus here is on society in general and she makes a point of contrasting her acclimatization at home with dissatisfaction at work, complaining that her job is non-developmental. The role of other nationalities in this is paramount for Kasia. For her Romanians are 
favoured above Poles and all others. Interestingly her proposed solution to these problems is through an appeal to a supposed 'neutrality' and 'objectivity' of the British upper managers. It seems not to occur to Kasia that the upper managers might be complicit in the situation, deliberately promoting Romanians. We have no direct evidence of this although a conversation with a British manager during the observation phase suggested a preference for Romanians due to their compliance.

An important element at work in Kasia's story is a notion of normality. For her the learning of idiomatic English is a passport to functioning 'normally' in a land where, in contrast to Poland, '[there are] many opportunities, and the only thing you have to do is reach for it'. However, her own attempts at advancement have been mixed, due, in her account, to the hostility of Romanian line managers, 'they sometimes behave as if it was their factory'.

Kasia's story reveals a complex and contradictory set of discourses at work: common workplace strife is shot through with notions of identity, the assumed identity of others, and complex notions of normality. In contrast to the static typologies of extant theorising in this field what is revealed through the discursive turn is a rich picture of individuals struggling to comprehend and manage the pressures of 'being migrants' in the contemporary workplace.

Significantly, and in contrast to Bowskill et al, this workplace, at least on the basis of our present knowledge, appears to exhibit few explicit pressures towards assimilation. Indeed the management of the organization seem content with the status quo. Returning to the theme with which we began this paper the perceived character of Poles may be the key to this. In contrast to the 'threatening' Muslims of Bowskill's work we may perhaps see Poles as offering a non-threatening, indeed positive, alternative to British workers. In such circumstances organizational managements have no need for assimilative strategies. This is an early and speculative conclusion, and more work is underway to test its veracity.

\section{References}

Anderson, B., Ruhs, M., Rogaly, B., and Spencer, S., 2006. Fair enough? Central and east european migrants in lowwage employment in the uk. Oxford: COMPAS.

Bourhis, R. Y., Moise, L. C., Perreault, S., and Senecal, S., 1997. Towards an interactive acculturation model: A social psychological approach. International Journal of Psychology, 32 (6), 369-386.

Bowskill, M., Lyons, E., and Coyle, A., 2007. The rhetoric of acculturation: When integration means assimilation. British Journal of Social Psychology, 46, 793-813.

Bron, A., and West, L., 2000. Time for stories: The emergence of life history methods in the social sciences. Journal of Contemporary Sociology, 37 (2), 157-169.

Chircov, V., 2009a. Introduction to the special issue on Critical Acculturation Psychology. Critical Acculturation Psychology, 33 (2), 87-93.

Chircov, V., 2009b. Critical psychology of acculturation: What do we study and how do we study it, when we investigate acculturation? Critical Acculturation Psychology, 33 (2), 94-105.

Chircov, V., 2009c. Summary of the criticism and of the potential ways to improve acculturation psychology. Critical Acculturation Psychology, 33 (2), 177-180.

Currie, S., 2007. De-skilled and devalued; the labour market experience of polish migrants in the uk following eu enlargement. The International Journal of Comparative Labour Law and Industrial Relations, 23 (1), 83-116.

Donnelly, E., Freedman, P. and Wilczek, B., 2008, Choice and constraint in migrant worker integration: the case of Polish workers in the British workplace. IREC, 23-25 June, Greenwich. 
Evans, C., 2007. Migrant workers in the south west. Exeter: SLIM.

Fitzgerald, I., 2006. Organising migrant workers in construction. Newcastle upon Tyne: TUC.

Fitzgerald, I., 2007. Working in the uk : Polish migrant worker routes into employment in the north east and north west construction and food processing sectors. London: Trades Union Congress.

French, S., and Mohrke, J., 2006. The impact of 'new arrivals' upon the north staffordshire labour market. Keele University.

Gaine, C., 2006. Recent immigration to the chichester district: Scale and impact. Chichester: University of Chichester.

Home Office. 2007. The economic and fiscal impact of immigration. London: TSO.

Home Office. 2009. Accession monitoring report may 2004 - december 2008. Home Office.

House of Lords, 2008. The economic impact of immigration. Volume 1: Report. London: The Stationery Office Limited.

Lsc. 2007. Migrant workers and the labour market. Coventry: Learning and Skills Council.

McGovern, P., 2007. Immigration, labour markets and employment relations: Problems and prospects. British Journal of Industrial Relations, 45 (2), 217-235.

Navas, M., Garcia, M. C., and Rojas, A. J., 2006. Acculturation strategies and attitudes of african immigrants in the south of spain: Between reality and hope. Cross-Cultural Research, 40 (4), 331-351.
Navas, M., Garcia, M. C., Sanchez, J., Rojas, A. J., Pumares, P., and Fernandez, J. S., 2005. Relative acculturation extended model (raem): New contributions with regard to the study of acculturation. International Journal of Intercultural Relations, 29 (1), 21-37.

Navas, M., Rojas, A. J., Garcia, M., and Pumares, P., 2007. Acculturation strategies and attitudes according to the relative acculturation extended model (raem): The perspectives of natives versus immigrants. International Journal of Intercultural Relations, 31 (1), 67-86.

People Management. 2006. Eastern european migrants are becoming employees of choice. People Management, 12, 13.

Piontkowski, U., Rohmann, A., and Florack, A., 2002. Concordance of acculturation attitudes and perceived threat. Group Process \& Intergroup Relations, 5 (3), 221-232.

Press Office. Latest immigration and asylum figures published. Home Office Press Releases. Available from: http:/ / press.homeoffice.gov.uk/pressreleases/immigration-and-asylumfigures [Accessed: 14 January 2008].

Salt, J., 2006. International migration and the united kingdom: Report of the united kingdom sopemi correspondent to the oecd, 2006. London: MRU.

Spencer, S., Ruhs, M., Anderson, B., and Rogaly, B., 2007. Migrants' lives beyond the workplace: The experience of central and east europeans in the uk. York: Joseph Rowntree Foundation.

Thomas, W. I., and Znaniecki, F. W., 1918. The polish peasant in europe and america. Monograph of an immigrant group. Chicago: University of Chicago Press. 